Whether the previous diet of the human mother may influence the capacity of the human baby to subsist on a purely vegetable diet for a given period after weaning is a point of interest worthy of study.

\title{
REFERENCES
}

Barton-Wright, E. C. \& Moran, T. (1946). Analyst, 71, 278.

Block, R. J. \& Mitchell, H. H. (1946-7). Nutr. Abstr. Rev. 16, 249.

Cary, C. A., Hartman , A. M., Dryden, L. P. \& Likely, G. D. (1946). Fed. Proc. $5,128$.

Chick, H. (1947). Chem. Ef Ind. p. 318.

Chick, H., Cutting, M. E. M., Martin, C. J. \& Slack, E. B. (1947). Brit. F. Nutrit. 1, 161.

Chick, H. \& Slack, E. B. (1945). Biochem. F. 39, xxii.

Chick, H. \& Slack, E. B. (1946). Lancet, 251, 601.

Chick, H. \& Slack, E. B. (1949). Biochem. F. 45, 211.

Dean, R. F. A. (1949). Mschr. Kinderheilk. 97,471 .

Dean, R. F. A. (195I). Brit. F. Nutrit. 5, 269.

Hartman, A. M. (1 946). Fed. Proc. 5, 137.

Hartman, A. M., Dryden, L. P. \& Cary, C. A. (1949). Arch. Biochem. 23, 165.

Hoagland, R. \& Snider, G. G. (1927). F. agric. Res. 34, 297.

Hove, E. I., Carpenter, L. E. \& Harrel, C. G. (1945). Cereal Chem. 22, 287.

Jones, D. B. \& Divine, J. P. (1944). F. Nutrit. 28, 41.

Jones, D. B. \& Gersdorf, C. E. F. (1923-4). F. biol. Chem. 58, i 17.

Jones, D. B. \& Gersdorf, C. E. F. (1925). F. biol. Chem. 64, 241.

Lusk, G. (1928). The Elements of the Science of Nutrition, 4th ed. Philadelphia: W. B. Saunders Co.

McCollum, E. V., Orent-Keiles, E. \& Day, H. G. (1939). The Newer Knowledge of Nutrition, $5^{\text {th }}$ ed. New York: The Macmillan Co.

Mitchell, H. H. (1923-4). F. biol. Chem. 58, 873 .

Mitchell, H. H. \& Carman, G. G. (1926). F. biol. Chem. 68, 183 .

Mitchell, H. H. \& Hamilton, T. S. (1929). The Biochemistry of the Amino Acids. American Chemical Society Monograph Series. New York: Chemical Catalog Co., Inc.

Osborne, T. B. \& Mendel, L. B. (1914). F. biol. Chem. 17, 325.

Osborne, T. B., Mendel, L. B. \& Ferry, E. L. (1919). Y. biol. Chem. 37, 223.

Ott, W. H., Rickes, E. L. \& Wood, T. R. (I948). F. biol. Chem. 174, 1047.

Rose, W. C. (1938). Physiol. Rev. 18, 109.

Slack, E. B. (1948). Nature, Lond., 16r, 2 II.

Snell, E. E. \& Wright, L. D. (1950). Ann. Rev. Biochem. 19, 277.

Stokstad, E. L. R. \& Jukes, T. H. (1949). Ann. Rev. Biochem. 18, 435.

Thomas, K. (1909). Arch. Anat. Physiol., Lpz., Physiol. Abt. p. 2 I9.

Wills, L. (195I). Brit. Y. Nutrit. 5, 265.

- Given in original as Gartman, obvious misprint,

\section{The Glinical Picture in Children Fed after Weaning on a Predominantly Vegetable Diet}

\author{
By LUCY WILLS, late of McCord's Zulu Hospital, Durban, \\ and the Royal Free Hospital, London
}

\section{Introduction}

The clinical findings in infants and children fed after weaning on predominantly vegetable diets is the subject of this paper; my experience has been chiefly with the African, so most of the space will be devoted to a description of the syndrome of malignant malnutrition, kwashiorkor, or fatty liver disease of infants as Waterlow calls it, as seen in the Bantu race. It must be understood that this syndrome, which I take to be the extreme expression of the ill-effects of such diets, is not limited to the African; it is seen in all races, and Czerny's 'Mehlnährschaden' is probably the same condition in European children. 
A study of populations living on diets consisting predominantly of carbohydrates suggests that there are three very constant ill-effects on the body. The first is on the haemopoietic organs; children and adults are either anaemic or have a tendency to develop an anaemia, generally macrocytic, when under stress. The second effect is on the liver; the lack of protein in the diet is associated with the development of fatty livers in children and with a high incidence of cirrhosis and malignant disease in the adult. The third effect which apparently results partly from the lack of protein itself and partly from the impaired liver function is a shortage of suitable protein so that the body has to call on its own supplies, as is shown by muscular wasting and by an abnormally low level of serum albumin; with the last is associated a tendency to develop oedema. Further, unless the diet contains a suitable mixture of vegetable products, there is often a high incidence of deficiency states due to inadequate supplies of the vitamins of the $\mathbf{B}_{\mathbf{2}}$ complex, skin lesions being especially frequent.

\section{The clinical material studied}

The material studied consisted of thirty-six consecutive cases of kwashiorkor admitted to McCord's Zulu Hospital, Durban, under the care of Dr Frank Walt (Walt, Wills \& Nightingale, 1950). The diagnosis was based on what we considered to be the essential clinical signs: anorexia, wasting particularly of the muscles which might be masked by oedema, an enlarged liver, and oedema associated with low values for serum proteins. Skin lesions, though not essential for diagnosis, were present in most of the cases.

The children varied in age from 3 months to 6 years. The histories, always unreliable, were depressingly uniform: the baby had been breast fed and then weaned on to a standard diet of samp (Kaffir corn) and mealie-meal porridge; no fresh milk or only minute quantities, no meat, eggs or fish and only the very occasional green vegetable. Generally, the mother said that the child had been well until a short time before when there had been an attack of diarrhoea followed by oedema. Sometimes there was a history of several previous attacks, and one atrophic case gave a history of severe oedema which had cleared up some time before admission.

The cases were of two types: the commoner was the oedematous, many of the children having gross oedema with anasarca; a few, six in all, were of the second type, and were in the last stages of wasting. These atrophic cases were the most severe; they were seen to pass from an oedematous condition to an atrophic one while under observation, and there seems no doubt that the atrophic state is the terminal stage of the disease. Most of the patients had diarrhoea on admission. Examination showed oedema to be present in thirty-two of the thirty-six cases; in thirty it was associated with an enlarged liver, which we assumed to be related to the existence of fatty infiltration (Pls. I and 2). Skin changes were very striking in the majority of the patients, though a few had clear skins. The hair was reddish brown, there was hyperpigmentation associated with areas of depigmentation. and often there were terrible sores and angular stomatitis. Except in one extremely anaemic child, the urine contained no albumin. Unlike Trowell's cases (Trowell \& Muwazi, I945), tropical diseases were absent; there was no case of hookworm infection. 
Haematological examination showed that all the children were suffering from a moderate normochromic, normocytic or slightly macrocytic anaemia, except in three cases, two fatal, where the anaemia was very severe. The serum proteins were of particular interest; they were estimated as a routine by the copper-sulphate method with use of Hoch's formula, $P=364(S-\mathrm{r} \cdot 006)$, where $P$ is the protein concentration in $\mathrm{g} . / \mathrm{roo} \mathrm{ml}$. serum and $S$ the apparent specific gravity of the serum (Hoch \& Marrack, 1945), and also by the biuret method. The mean value for total serum proteins on admission was $4.5 \mathrm{~g}$. $/ 100 \mathrm{ml}$. with range from 3.5 to $5.6 \mathrm{~g}$. $/ 100 \mathrm{ml}$.; in seven instances only, including two of the atrophic ones, was it over $5.0 \mathrm{~g} / 100 \mathrm{ml}$. The low values for total serum proteins were due to decrease in the albumin fraction, the globulin values being normal. On treatment the rise in the protein level was extremely rapid; it often started on the 2 nd day, and by the 16 th-20th day the mean level was $7.0 \mathrm{~g} / 100 \mathrm{ml}$., a value agreeing closely with that of $7 \cdot 1 \mathrm{~g} / 100 \mathrm{ml}$. found in a control group of healthy Bantu children.

Three patients were clinically jaundiced, and two of them died within $24 \mathrm{hr}$. of admission with grossly enlarged and fatty livers.

\section{Findings at autopsy}

Limited post-mortem examinations were made on the four fatal cases, two of each type. In all of them the liver showed gross fatty changes; in the two oedematous ones, both under 2 years of age, the organ weighed $x \mathrm{lb}$. and $\mathrm{I}$ lb. 2 oz., respectively. One of the atrophic cases had a small liver, suggestive of early cirrhosis. The pancreas showed no pathological changes. Two of the patients had died from terminal bronchopneumonia, the other two apparently from liver failure.

\section{Treatment}

The treatment was very simple. We argued that the children were dying of protein starvation and excess carbohydrate, and that with such fatty livers administration of fat was contra-indicated, so we decided to force-feed them with maas, which is curds made from skim milk, and with maas only, to which, after a week, skim milk powder was added; later a full mixed diet supplemented with extra milk was given. Improvement was rapid in most cases. After a few days a marked diuresis set in resulting in a rapid loss of weight which was followed by a steady gain. The diarrhoea generally ceased in a few days with no other treatment. The liver gradually decreased in size. The serum proteins increased steadily but the blood count fell slightly at first and then rose slowly, the results being similar to those observed by Altmann (1948) and by Walters, Rossiter \& Lehmann (1947) in returned Indian prisoners of war. The last workers showed the fall in the red-cell level to be due to an increase in plasma volume. If a similar increase in plasma volume explained the fall in red-cell level in our cases, the rate of protein regeneration must have been even more striking than the figures suggest, as we never observed a fall in serum protein level once treatment had begun.

The crude death rate in our series was I $\%$, or $2 \cdot 8 \%$ if all deaths within $24 \mathrm{hr}$. of admission are excluded as was done by Altmann (1948) in his calculation of death rate. The latter figure $m_{\nu}$, be compared with a corrected value of $20 \%$ for Altmann's series 
and of $6 \%$ for the series of cases treated with hog's stomach by Gillman \& Gillman (1946). The death rate for oedematous cases was low in Altmann's series and in ours, being 4.5 and $3.3 \%$, respectively. It is the atrophic cases that are so fatal, and the number of such in any series will determine the death rate in that series.

\section{Discussion}

In my opinion the essential causative factor in this condition is associated with a deficiency of animal protein. That animal protein rather than vegetable protein is essential is not proven, but the evidence in favour of its being so is suggestive. The syndrome occurs in many lands with varied national diets, the common factor in all being a lack of animal protein and an excess of carbohydrate in the diet, and very frequently, though not invariably, a rather low supply of calories. Whipple and his colleagues in their classical experiments showed that for protein regeneration, animal proteins favour the formation of serum albumin, and vegetable protein, with the exception of soya-bean protein, that of serum globulins (McNaught, Scott, Woods \& Whipple, 1936). Milk is the best known curative agent.

If the liver lesion is the primary one and a deficiency of protein the essential causative factor, it is natural that lipotrophic factors such as methionine and choline should have been considered as possible curative agents. Gillman \& Gillman (1945) and Waterlow (1948) used the substances with no success. Vitamins, too, have been tried and found wanting. Milk is the basis of successful treatment.

Taylor \& Chhuttani (1945) studied the incidence of anaemia among Indian troops of whom 17,000 were meat eaters and I 88 were vegetarians, all living under good conditions, with a low sick rate. The men had been on army rations for 2 years. They had received the same basic rations which yielded about $3000 \mathrm{Cal}$. and $80 \mathrm{~g}$. vegetable protein but the meat eaters received an additional ration of $6 \mathrm{oz}$. fresh mutton with bone daily, the vegetarians one of $4 \frac{1}{2} \mathrm{oz}$. tinned milk 3 times a week, and $\frac{3}{4} \mathrm{oz}$. ghee and $3 \mathrm{oz}$. atta or rice twice a week, but the milk was frequently not taken. The incidence of anaemia severe enough for admission to hospital was at the yearly rate of $58.5 / 1000$ for macrocytic anaemia among vegetarians, and of 2.6/1000 for normocytic or microcytic, hypochromic anaemia among meat eaters. The difference was even more striking in the incidence of anaemias with red-cell counts of 2 millions or less or a haemoglobin value below $5.8 \mathrm{~g}$. $/ 100 \mathrm{ml}$; among vegetarians the rate was $24.7 / 1000$, and among meat eaters $0 \cdot 16 / 1000$. Anaemia, especially macrocytic anaemia, is one of the most constant findings among peoples who depend for their protein on vegetable sources. Indian troops on active service had a far higher incidence of anaemia than British troops exposed to the same risks of malaria and other tropical diseases: the meat eaters suffered as well as the vegetarians, since their meat ration, which had to be fresh owing to supply difficulties, might reach them only once a fortnight (Marriott, 1945). Indian prisoners of war suffered even more severely from macrocytic anaemia, as their diet was extremely poor, often completely vegetarian and low in calories.

The evidence for the occurrence of protein deficiency in adults on predominantly vegetable diets is more circumstantial. It is idle to look in adults for the same syndrome as in children, since the adults of those populations where the incidence of malignant 


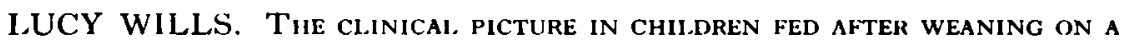
PREDOMINANTLY VEGETABLE DIET

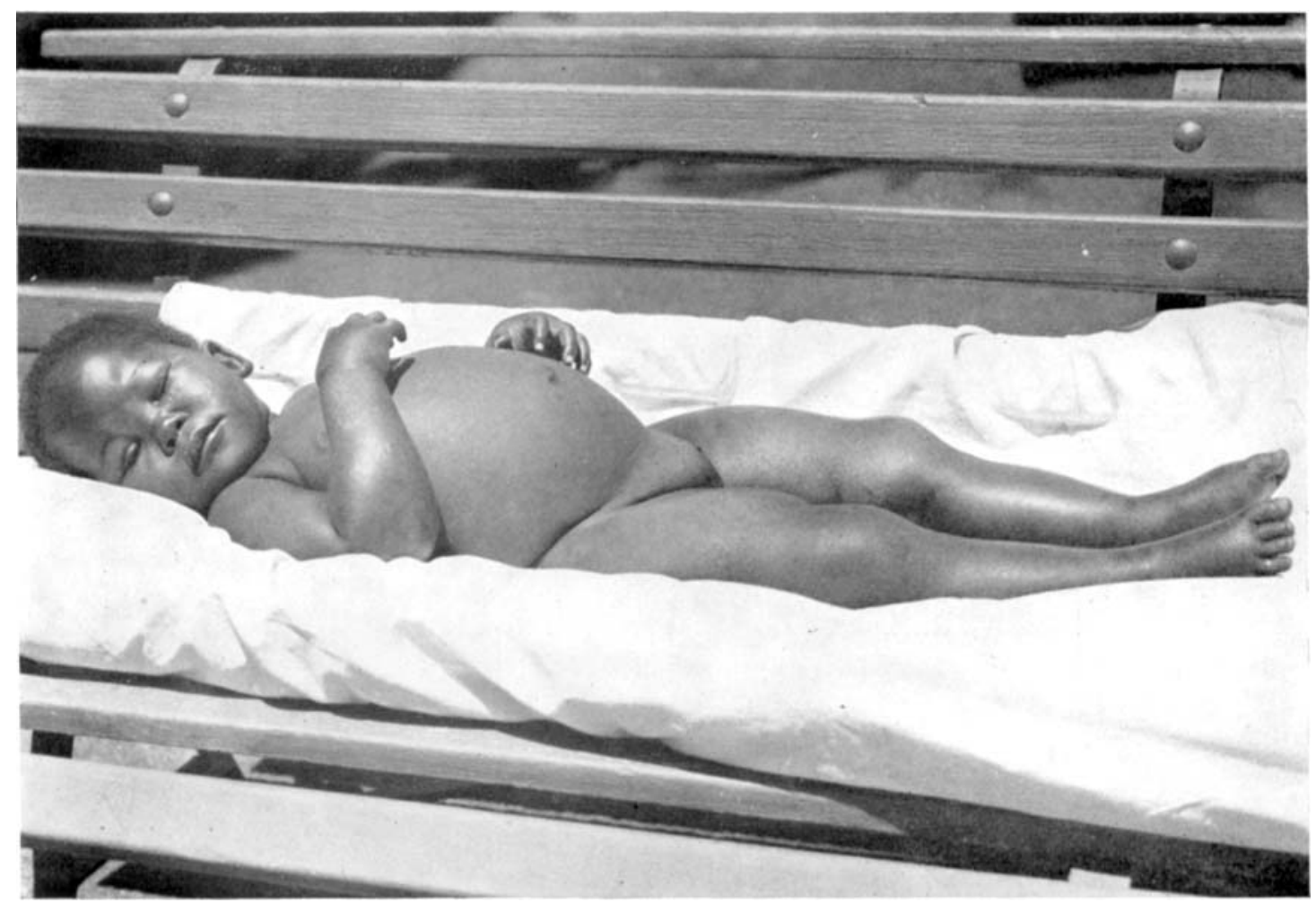


LUCY WILLS. The CLINICAL PICTURE IN CHILdREN FED AFTER WEANiNG

Plate 2 ON A PREDOMINANTLY VEgETABLE DIET

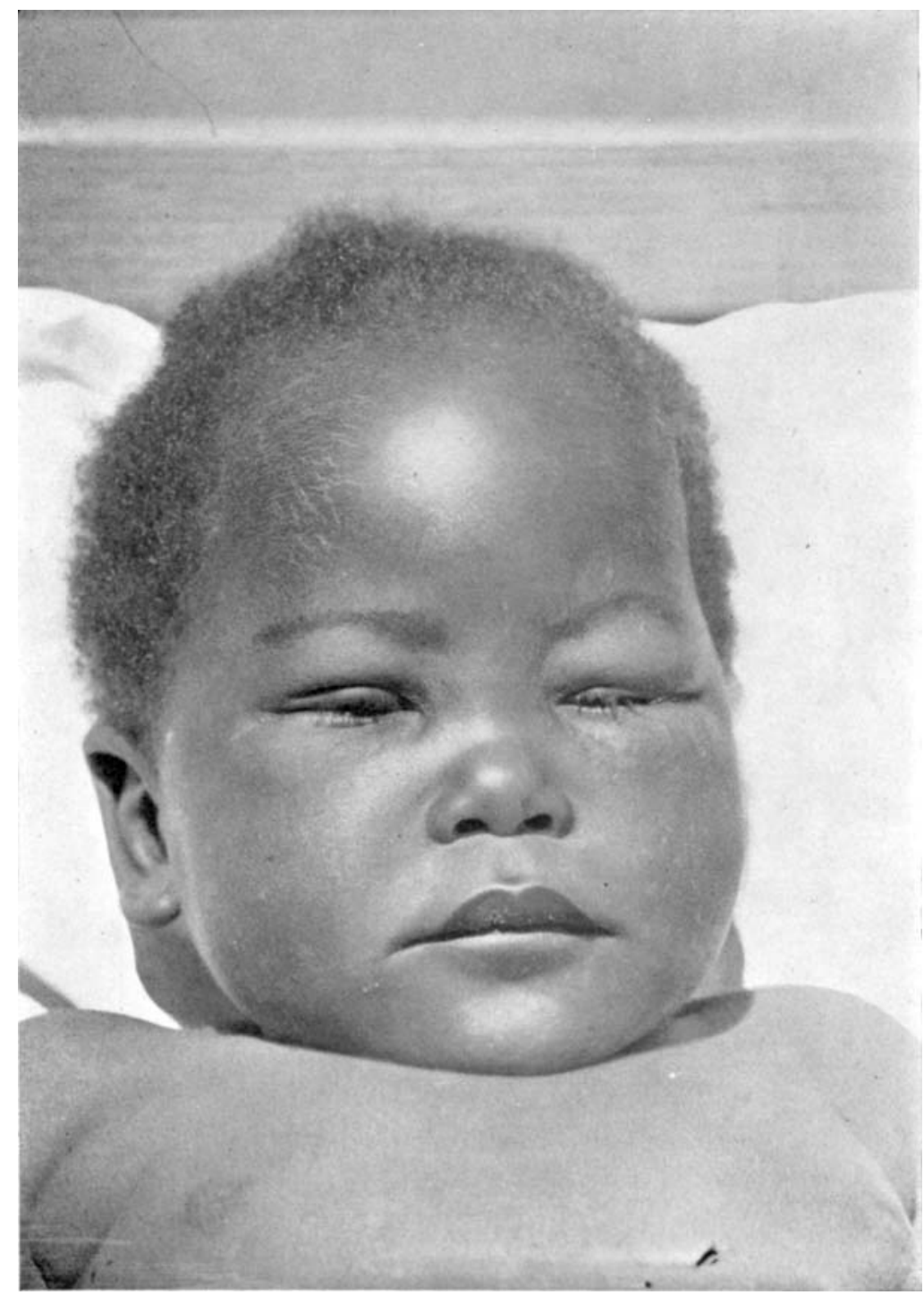

British fournal of Nutrition, Vol. 5, No. 2 
malnutrition is high in the children will themselves have suffered the same stresses in their infancy. One could expect, therefore, that the liver lesion would progress in any individuals who had failed to recover completely from malignant malnutrition in infancy. In the children's departments of the hospitals in the West Indies and South Africa, one sees small patients, generally boys, with every grade of liver damage from an enlarged hard liver to the final stages of advanced cirrhosis. In those countries and in India routine post-mortem examinations and hospital records provide the evidence of a very high incidence of cirrhosis and carcinoma of the liver; the incidence is far higher than among Europeans and the lesions occur at a much earlier age. True malignant malnutrition also is found among adults, and Trowell \& Muwazi (I945) quote a figure of $10 \%$ of all admissions to the Uganda Medical School Hospital at Kampala.

The clinical picture in populations weaned on to and existing on diets predominantly or almost entirely of vegetable origin includes underdevelopment, poor physique, anaemia, liver damage associated with cirrhosis and malignant disease, abnormal values for serum proteins with a tendency to develop oedema, and of ten all the signs and symptoms of vitamin $\mathrm{B}_{2}$-complex deficiencies. Given a diet with an inadequate supply of calories derived mainly from one or more staple carbohydrates and with little or no animal protein, and malignant malnutrition will appear with all its sequelae. That adequate calories from mixed vegetable staples can prevent the syndwome and give maximum health has yet to be demonstrated.

\title{
REFERENCES
}

Altmann, A. (1948). Clin. Proc., F. Cape Town Post-Grad. med. Assoc. 7, 32.

Gillman, T. \& Gillman, J. (1945). Nature, Lond., 155, 634.

Gillman, T. \& Gillman, J. (1946). Lancet, 251, 446.

Hoch, H. \& Marrack, J. (1945). Brit. med. $\mathcal{~ . ~ i i , ~} 151$.

McNaught, J. B., Scott, V. C., Woods, F. M. \& Whipple, G. H. (1936). F. exp. Med.63, 277.

Marriott, H. L. (1945). Lancet, 248, 679.

Taylor, G. F. \& Chhuttani, P. N. (1945). Brit. med. F. i, 800.

Trowell, H. C. \& Muwazi, E. M. K. (1945). Trans. R. Soc, trop. Med. Hyg. 39, 229.

Walt, F., Wills, L. \& Nightingale, R. P. (1950). S: Afr. med. F. 24, 920.

Walters, J. H., Rossiter, R. J. \& Lehmann, H. (1947). Lancet, 252, 205.

Waterlow, J. C. (1948). Spec. Rep. Ser. med. Res. Coun., Lond., no. 263.

\section{EXPLANATION OF PLATES}

Pl. I. Bantu child, aged about 18 months, with the oedematous form of kwashiorkor, showing severe generalized anasarca and moderate skin lesions.

P1. 2. Head of same child as in P1. 1. Note pale, scanty hair and severe oedema of face.

Both plates by the courtesy of the Senior Pathologist, Central Pathological Laboratory, Durban, South Africa.

\section{The Nutritional Adequacy of a Vegetable Substitute for Milk}

\author{
By R. F. A. DEAN, Department of Experimental Medicine, \\ University of Cambridge and Medical Research Council
}

The problem of supplying a substitute for milk can be resolved into the separate problems of finding substitutes for the various components: minerals, carbohydrate, fat, protein and vitamins. 